\title{
Evidence for natural attenuation of 1,4-dioxane in a glacial aquifer system
}

\author{
Leah E. Jackson ${ }^{1,2} \cdot$ Lawrence D. Lemke ${ }^{1,3}$ \\ Received: 18 December 2018 / Accepted: 7 August 2019 / Published online: 2 October 2019 \\ (C) The Author(s) 2019
}

\begin{abstract}
Although 1,4-dioxane is generally thought to be recalcitrant, recent studies suggest it may degrade in the subsurface under ideal conditions. A fuller understanding of natural attenuation processes affecting 1,4-dioxane is therefore needed to assess its potential for in situ bioremediation. This investigation employed multiple lines of evidence to evaluate attenuation of 1,4-dioxane at the Gelman Site beneath the city of Ann Arbor, Michigan, USA. Data from a network of groundwater monitoring wells were used to determine attenuation metrics at individual wells and at the scale of a prominent 1,4-dioxane plume. A series of plume maps and historical remediation data were used to calculate changes in aqueous phase mass storage, mass influx rates, and mass removal rates over a 12-year period (2005-2017). Individual point and plume-scale metrics indicate that attenuation may be occurring at rates too small to meaningfully contribute to remediation results at the site. Conversely, plume-scale mass balance calculations reveal a 1,4-dioxane storage surplus for the first 6 years, followed by a storage deficit during the remaining 6 years that cannot be explained by mass influx or removal estimates, respectively. Mass balance deficits observed in this aquifer system are attributable to biodegradation and/or unrecognized discharge to surface water and storm drain systems at rates similar to remedial pump-andtreat mass removal during 2011-2017.
\end{abstract}

Keywords Contamination $\cdot$ Solute transport $\cdot$ Natural attenuation $\cdot$ Groundwater monitoring $\cdot$ USA

\section{Introduction}

1,4-Dioxane is classified as a Group B2 probable human carcinogen (USEPA 2006). When released into groundwater, its high miscibility and low retardation factor (Mohr 2010; USEPA 2017) limit the ability of processes such as sorption to attenuate 1,4dioxane concentrations as plumes migrate. Until recently, researchers thought that its molecular structure also made it resistant to biodegradation (DiGuiseppi et al. 2016); consequently, 1,4-dioxane is considered a persistent contaminant of concern.

Electronic supplementary material The online version of this article (https://doi.org/10.1007/s10040-019-02028-6) contains supplementary material, which is available to authorized users.

Lawrence D. Lemke

L.D.Lemke@cmich.edu

1 Department of Earth and Atmospheric Sciences, Central Michigan University, 314 Brooks Hall, Mount Pleasant, MI 48859, USA

2 Earth and Ecosystem Science Program, Central Michigan University, Mount Pleasant, MI, USA

3 Institute for Great Lakes Research, Central Michigan University, Mount Pleasant, MI, USA
Ex-situ remediation technologies such as pump-and-treat with advanced oxidation processes, are the primary methods employed to treat 1,4-dioxane contaminated aquifers (Zenker et al. 2003). Extracted water containing 1,4-dioxane is mixed with hydrogen peroxide and ozone, or exposed to ultraviolet light, to break the carbon bonds (Stefan and Bolton 1998; Zenker et al. 2003). These processes are often expensive and less than 100\% effective (USEPA 2006; Stepien et al. 2014).

Recent laboratory experiments have shown the potential for both aerobic ( $\mathrm{Li}$ et al. 2010, 2015) and less commonly anaerobic (Shen et al. 2008) biodegradation of 1,4-dioxane. Li et al. (2010) investigated 1,4-dioxane degradation in biostimulated and bioaugmented microcosms under low to warm temperature conditions. Li et al. (2015) measured biodegradation of 1,4-dioxane in environmental samples from three sites in California. Shen et al. (2008) used enriched iron(III)-reducing bacteria cultivated from sludge at a wastewater treatment plant to degrade 1,4-dioxane.

Before in situ bioremediation can be effectively employed to address 1,4-dioxane, a fuller understanding of natural attenuation processes affecting 1,4-dioxane is needed. Provided that sufficient data are available, attenuation - including biodegradation under natural conditions - can be assessed 
through field data analyses combined with conceptual and mathematical modeling (Alvarez and Illman 2006). Adamson et al. (2015), for example, used statistical analysis of 1,4-dioxane measurements to determine that natural attenuation of 1,4-dioxane may be occurring in the presence of trichloroethylene, 1,1,1-trichloroethane, or 1,1-dichloroethene at 191 sites selected from the California GeoTracker database and 131 monitoring wells at 14 United States Air Force installations in the Environmental Restoration Program Information Management System. In another study, Gedalanga et al. (2016) used a combination of traditional lines of evidence (i.e., temporal and spatial trends, source and plume mass estimates, and fate and transport modeling) along with biomarker and compound specific isotope analysis to evaluate intrinsic 1,4-dioxane biodegradation at a landfill site.

The purpose of this study is to evaluate potential natural attenuation of 1,4-dioxane, which is present without any known co-contaminants, in a glacial aquifer system beneath Ann Arbor, Michigan. To achieve this goal, multiple methods were employed including point attenuation analysis at individual monitoring wells, bulk attenuation analysis along a longitudinal plume axis, and mass balance and spatial moment analyses throughout the study area. The results add to a growing body of evidence suggesting that 1,4-dioxane is subject to natural attenuation processes including biodegradation.

\section{Background and conceptual site model}

1,4-Dioxane was used at the former Gelman Sciences, Inc. site (hereafter referred to as the Gelman Site), in Washtenaw County, Michigan, over a period of approximately 25 years between 1960 and 1985. The release history is not well documented. The source area, where processed water containing 1,4-dioxane leached into the subsurface from unlined wastewater disposal ponds and a spray irrigation field (Mohr 2010), is shown in Fig. 1. The underlying glacial aquifer system sits within the Fort Wayne moraine (a remnant of the Pleistocene glaciation) and consists of interconnected shallow and deep aquifers with different hydraulic gradients (Cypher and Lemke 2009; Frahm 2011; Lemke et al. 2013; Pappas 2016; Pruehs 2016). The unconsolidated glacial sediments are 50 $90 \mathrm{~m}(160-300 \mathrm{ft})$ thick and consist of approximately twothirds aquifer and one-third aquitard material by volume as interpreted by Frahm (2011). Site investigations have documented 1,4-dioxane migration eastward and westward from

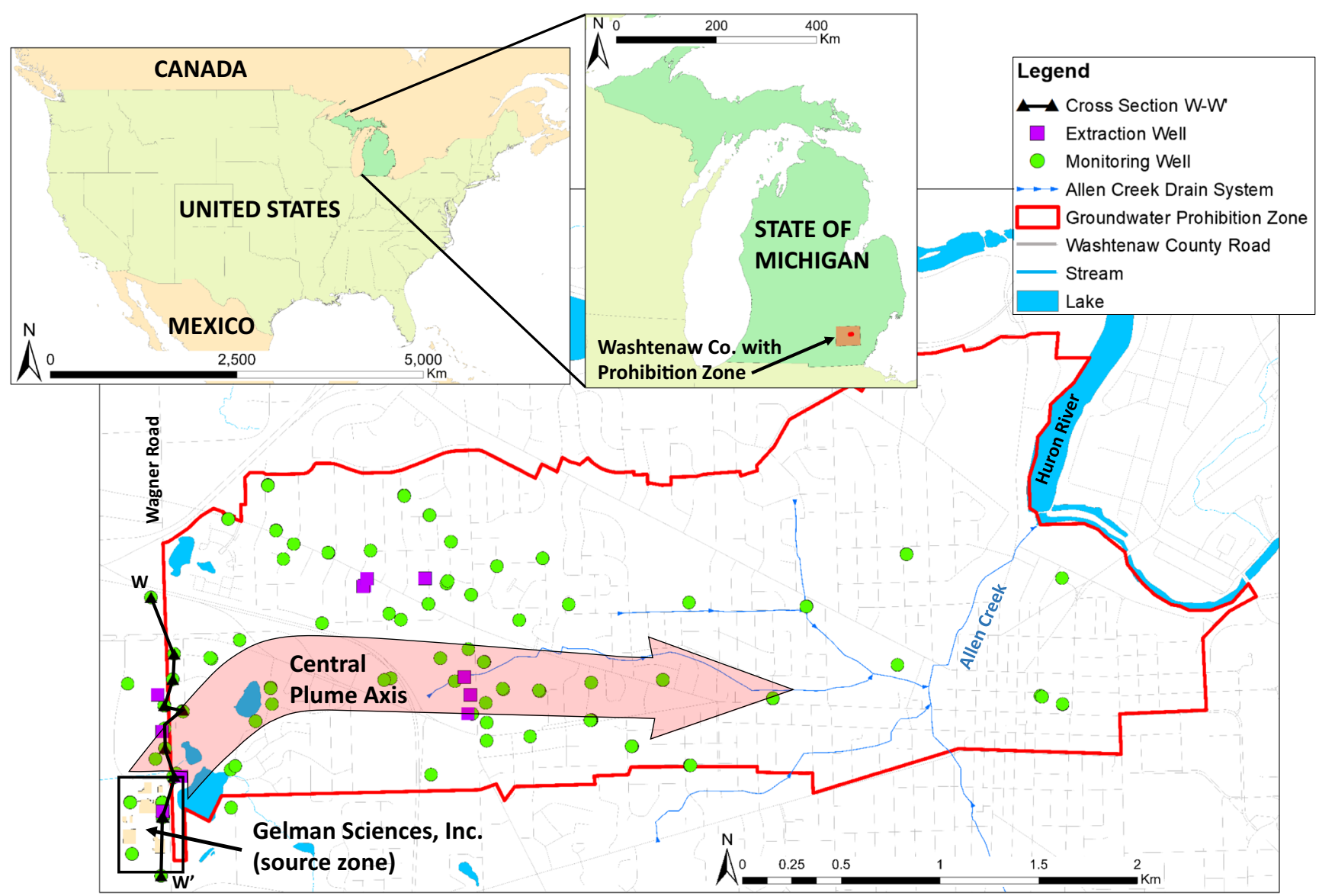

Fig. 1 Map of the study area in central Washtenaw County, Michigan, USA showing the location of the Gelman Sciences source area and cross section $\mathrm{W}-\mathrm{W}^{\prime}$. The red line identifies the boundary of the groundwater use prohibition zone defining the Eastern Area 
the Gelman property at different depths within the aquifer system (e.g., Pall Life Sciences 2006, 2007a, b, 2009).

Characterization of the Gelman Site began more than three decades ago. Water sampling in the mid-1980's detected 1,4dioxane in groundwater adjacent to the source zone at concentrations as high as $210,000 \mathrm{ppb}(\mu \mathrm{g} / \mathrm{L})$ (Fotouhi et al. 2006). Shortly thereafter, remediation efforts began with the installation of monitoring and extraction wells that have grown to a network of more than 230 shallow, intermediate, and deep wells. After 1,4-dioxane was discovered in an Ann Arbor municipal water supply well (City of Ann Arbor 2004), an institutional control prohibiting groundwater removal for human use was established by court order in 2005. The Eastern Area of the Gelman Site, delineated by the groundwater removal prohibition zone shown outlined in Fig. 1, provides the setting for this investigation. Along with a series of wells located adjacent to Wagner Road on its western edge, the Eastern Area includes 12 extraction wells (Table 1) and approximately 100 monitoring wells with data on extraction rates, static water levels, and 1,4-dioxane concentrations. In 2017, Michigan regulators reduced drinking water standards for 1,4-dioxane in groundwater from 85 to $7.2 \mathrm{ppb}$. Recent monitoring well sampling within the prohibition zone indicates decreasing 1,4-dioxane concentrations in some wells; however, several of these wells continue to exceed the revised Michigan standard by more than 1,000 ppb.

1,4-Dioxane in the Eastern Area originated in the Gelman Sciences source zone and migrated eastward across Wagner Road along complex pathways through the glacial aquifer system. Hydraulic conductivities inferred from pump tests, coupled with eastward sloping hydraulic gradients, yield seepage velocities in the range of $0.2-0.3 \mathrm{~m} /$ day $(0.5-1 \mathrm{ft} /$ day $)$.

Table 1 Summary of Eastern Area 1,4-dioxane extraction well data (2005-2017)

\begin{tabular}{lll}
\hline Well & $\begin{array}{l}\text { Average annual pumping } \\
\text { rate (GPM) }\end{array}$ & Mass removed (kg) \\
\hline AE3 & 19 & 27 \\
LB1 & 70 & 752 \\
LB2 & 53 & 194 \\
LB3 & 58 & 463 \\
LB4 & 79 & 385 \\
DOLPH (TW-2) & 33 & 82 \\
TW-12 & 11 & 6 \\
TW-16 & 17 & 114 \\
TW-18 & 176 & 2,084 \\
TW-19 & 67 & 666 \\
TW-21 & 70 & 275 \\
TW-23 & 43 & 31 \\
Sum & - & 5,079 \\
\hline
\end{tabular}

${ }^{\mathrm{a}}$ Gallons per minute $\left(3.785 \mathrm{~L} \mathrm{~min}^{-1}\right)$
Concentrations in the source area have decreased from historically high values of 10,000-200,000 ppb to current concentrations of 2,000 ppb or less in response to pump-and-treat activities over the past two decades. West of Wagner Road, the vast majority of remedial mass removal occurred between 2001 and 2010. Many of the extraction wells in the source area exhibit asymptotic concentration declines to levels approaching 100-900 ppb (see Fig. S1 of the electronic supplementary material (ESM). This indicates that back diffusion of 1,4-dioxane from low permeability zones now serves as a secondary source west of Wagner Road. 1,4-Dioxane migration from the Gelman Sciences source zone into the Eastern Area decreased in response to the installation of two purge wells along Wagner Road: TW-18, which became operational in January 2006; and TW-21, which began pumping in June 2010. Complete hydraulic containment has not been established, however, so the flux of 1,4-dioxane migrating from the source area into the Eastern Area is inferred to have continued at a declining rate over time.

Approximately 5,100 kg of 1,4-dioxane have been removed from the Eastern Area since 2005 (Table 1) using a continuous pump-and-treat system. Average annual pumping rates and annual 1,4-dioxane mass removed by each extraction well are given in Tables S1 and S2 of the (ESM), respectively. 1,4-Dioxane concentrations observed in monitoring wells within the prohibition zone have been reduced from historical highs of approximately $10,000 \mathrm{ppb}$ to levels between 1,000-2,000 ppb. These reductions, which are attributed to ongoing remediation efforts, may have been enhanced by natural attenuation.

Because the total mass of 1,4-dioxane released at the site is undocumented, it is difficult to estimate the amount of 1,4dioxane that remains in the aquifer system. Nevertheless, changes in the distribution of 1,4-dioxane over time in the Eastern Area can be inferred from a series of concentration maps drawn using measurements from the monitoring well network. These maps are contained in reports posted on the Michigan Department of Environment, Great Lakes, and Energy (EGLE) - formerly Michigan Department of Environmental Quality (MDEQ) - Gelman website (MDEQ 2018a, b). Further, the maps, which provide a basis for the mass balance analysis described in the following, depict advancement of the then-applicable 85 ppb concentration contour to a position approximately $3 \mathrm{~km}$ east of the western boundary of the Eastern Area (Fig. 2), where it has remained more or less stationary since 2011.

Two potential hypotheses could explain the apparent stagnation of the inferred leading edge of the $85 \mathrm{ppb}$ isoconcentration line. The current network of monitoring wells in the downgradient portion of the Eastern Area may be insufficient to track 1,4-dioxane as it migrates eastward toward the Huron River. Alternatively, natural attenuation could be degrading 1,4dioxane at a rate approximately equal to that which advective and 


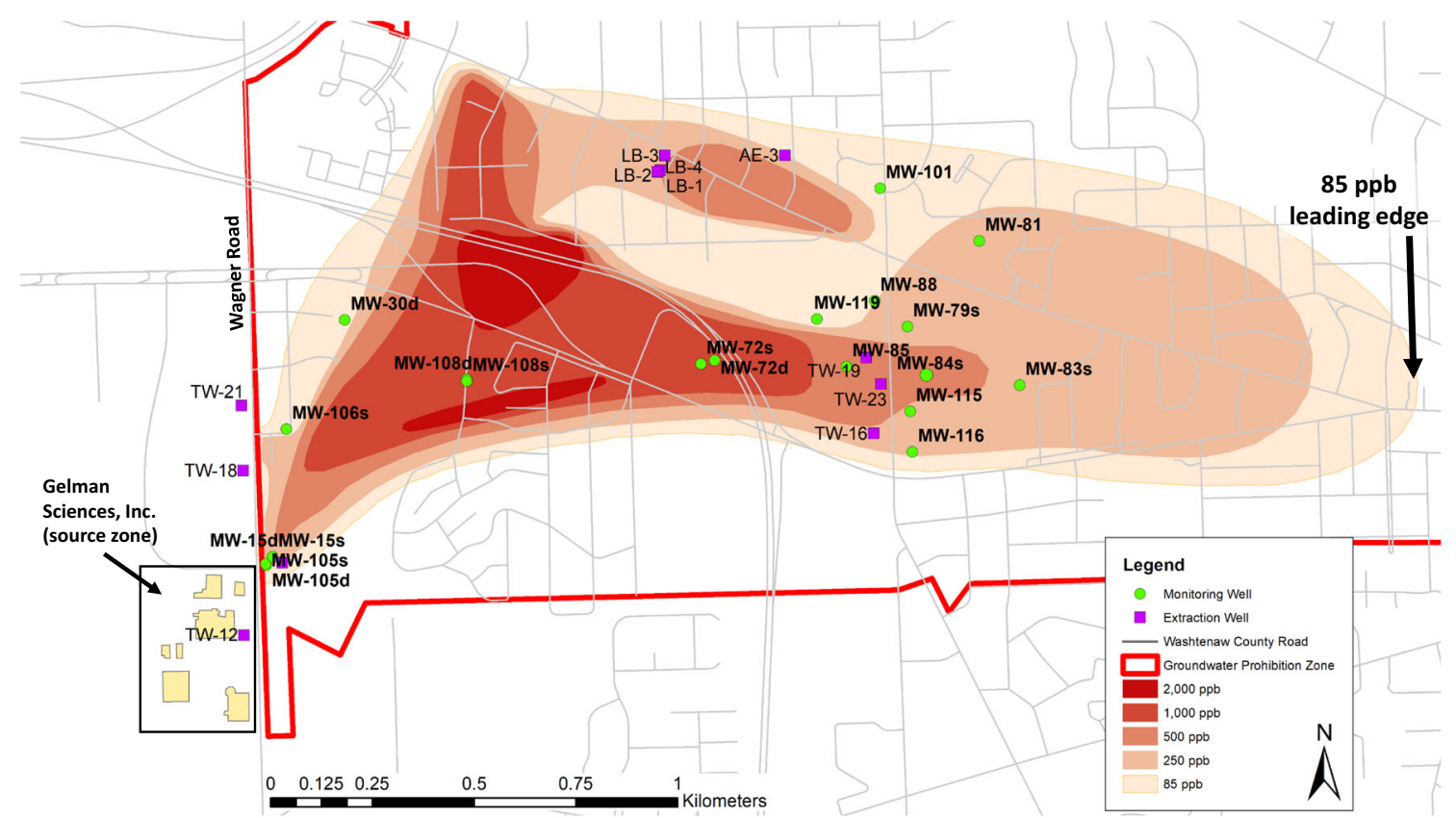

Fig. 2 Approximate position of the leading edge of the plume defined by the $85 \mathrm{ppb}$ isoconcentration line in 2017. The source zone is outlined in black. Wagner Road, the western boundary of the prohibition zone, is annotated. Monitoring and extraction wells used in the analyses are labeled

dispersive flux transport dioxane to the leading edge of the plume. Evaluation of the latter hypothesis provided the primary motivation for this investigation.

\section{Methods}

Multiple lines of evidence were used to evaluate natural attenuation within the Eastern Area of the Gelman Site. These included order-of-magnitude, point attenuation, and half-life analyses of concentration histories at individual wells, in addition to bulk attenuation, mass balance and spatial moment analyses to examine overall plume movement and evolution (Table S3 of the ESM). The investigation at individual wells focused on twenty Eastern Area monitoring wells experiencing concentration reductions over time with trends potentially resulting from natural attenuation processes. Bulk attenuation analysis examined 13 wells positioned along the inferred central axis of the plume to characterize how distance from the source zone relates to observed concentration changes. Mass balance and spatial moment analyses relied on the greater population of monitoring wells located in the Eastern Area and the adjacent source area.

\section{Order-of-magnitude reduction}

Order-of-magnitude values quantify the reduction of 1,4-dioxane concentration at individual monitoring wells. They were determined by taking the $\log _{10}$ of maximum concentration ratios:
$\mathrm{OM}_{\mathrm{red}}=-\log _{10}\left(C_{t} / C_{0}\right)$

where $\mathrm{OM}_{\text {red }}$ is the order of magnitude reduction, $C_{t}$ is the most recent (2017) yearly maximum concentration, and $C_{0}$ is the historic maximum concentration detected in each well.

\section{Point attenuation rates and half-lives}

Point attenuation analysis was used to estimate first-order contaminant decay rates in individual monitoring wells, which were subsequently used to extrapolate the time required for 1,4-dioxane concentrations to decrease to the relevant Michigan standard at the respective well locations. Exponential regression of maximum yearly concentrations versus time yielded a first-order point decay rate coefficient $\left(K_{\text {point }}\right)$ from the slope - an example is shown in Fig. S2 of the ESM. The length of time needed to reduce concentrations by one half was then determined as:

$t_{1 / 2}=\frac{\ln (2)}{K_{\text {point }}}$

where $t_{1 / 2}$ is the half-life of the contaminant concentration at each well and $K_{\text {point }}$ is the regression slope from the exponential regression performed at each well.

The time required to reduce 1,4-dioxane concentrations to acceptable regulatory standards was determined by:

$t=\frac{-\ln \left[\frac{C_{\text {goal }}}{C_{\text {start }}}\right]}{K_{\text {point }}}$ 
where $C_{\text {goal }}$ is the applicable criterion and $C_{\text {start }}$ is the $y$-intercept value from the exponential regression (USEPA 2002).

\section{Bulk attenuation}

1,4-Dioxane reduction in response to all attenuation processes (e.g., dispersion, sorption, biodegradation) was evaluated at the plume scale using maximum observed concentrations at wells located along the inferred axis of the plume. The natural log of the historical maximum concentration for each well was plotted against the distance from the source zone on the Gelman property to define a bulk attenuation decay coefficient (USEPA 2002):

$K_{\text {bulk }}=\left(\frac{d C}{d x}\right)\left(\frac{V_{\mathrm{s}}}{R}\right)$

where $\frac{d C}{d x}$ is the change in concentration with respect to the distance from the source, $V_{\mathrm{s}}$ is the seepage velocity (assumed to be $110 \mathrm{~m} /$ year), and $R$ is the retardation factor (assumed to be 1.0). If the effects of dispersion and sorption are small, $K_{\text {bulk }}$ will approximate a first-order biodegradation rate (USEPA 2002).

The time required for any part of the plume to attenuate to Michigan groundwater standards as it migrates downgradient can be determined by:

$t=\frac{-\ln \left[\frac{C_{\mathrm{goal}}}{C_{\mathrm{dgw}}}\right]}{K_{\text {bulk }}}$

where $C_{\text {goal }}$ is the applicable criterion, and $C_{\mathrm{dgw}}$ is the maximum measured concentration at a specified well downgradient from the source zone. Additionally, the distance contaminants will travel $(L)$ before concentrations diminish to $C_{\text {goal }}$ was calculated using:
$L=\frac{V_{\mathrm{s}}}{R} t$

where $t$ is the travel time determined from Eq. (5).

\section{Mass balance}

Changes in 1,4-dioxane mass storage within the Eastern Area aquifer system were analyzed using three components: (1) total influx of 1,4-dioxane crossing Wagner Road into the prohibition zone; (2) annual integrated estimate of total mass-in-place removed through pump-and-treat remediation efforts; and (3) total mass-in-place determined from Gelman concentration maps for 2005-2017.

The annual mass flux of 1,4-dioxane into the Eastern Area during 2008, 2012, and 2016 was estimated using hydraulic conductivity distributions (Fig. 3) and concentration contours along a profile parallel to Wagner Road (Fig. 4). Similar cross section concentration profiles for years 2012 and 2016 are included in Figs. S3 and S4 of the ESM. Hydraulic gradients near Wagner Road ranging from $6.8 \times 10^{-4}$ to $2.1 \times 10^{-3}$ were estimated from equipotential maps at shallow and deep plume levels (FTCH 2009a, b; Fleis and Vandenbrink, 2012a, b, $2016 \mathrm{a}, \mathrm{b})$. Horizontal hydraulic conductivity values assigned to aquifer $(35 \mathrm{~m} /$ day $)$ and aquitard $(0.023 \mathrm{~m} /$ day $)$ intervals were obtained from Pruehs (2016). Pruehs' (2016) analysis suggested that bedrock faults and fractures had relatively little effect on 1,4-dioxane transport, so potential dioxane transport through the Mississippian Coldwater Shale bedrock was neglected. Mass flux, calculated as the product of concentration and volumetric water flux determined using Darcy's Law, was integrated over the area of each cross section (Figs. 3 and 4; Figs. S3 and S4 of the ESM) at a resolution of $0.3 \mathrm{~m} \times 0.3 \mathrm{~m}$ $(1 \mathrm{ft} \times 1 \mathrm{ft})$ with an assumed effective porosity of $30 \%$.

The annual mass of 1,4-dioxane removed through remediation was determined from monthly National Pollutant Discharge Elimination System (NPDES) reports posted on
Fig. 3 Cross-section $\mathrm{W}-\mathrm{W}^{\prime}$ modified from Frahm (2011) showing the distribution of aquifer (yellow) and aquitard (green) hydrofacies along the western boundary of the Eastern Area at Wagner Road. View looking downgradient. W-W' profile location shown on Fig. 1. Vertical exaggeration 6:1

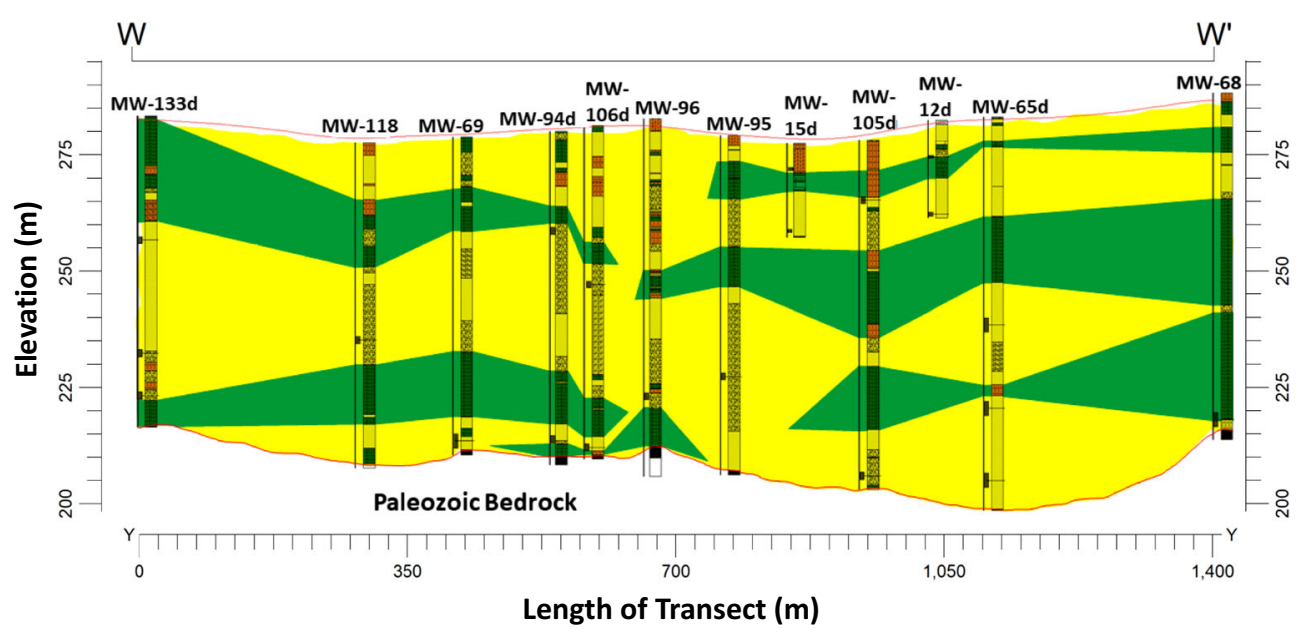


Fig. 42008 1,4-dioxane concentration (ppb) used in integrated mass flux calculations. View looking downgradient. W$\mathrm{W}^{\prime}$ profile location shown on Fig. 1. Vertical exaggeration 6:1

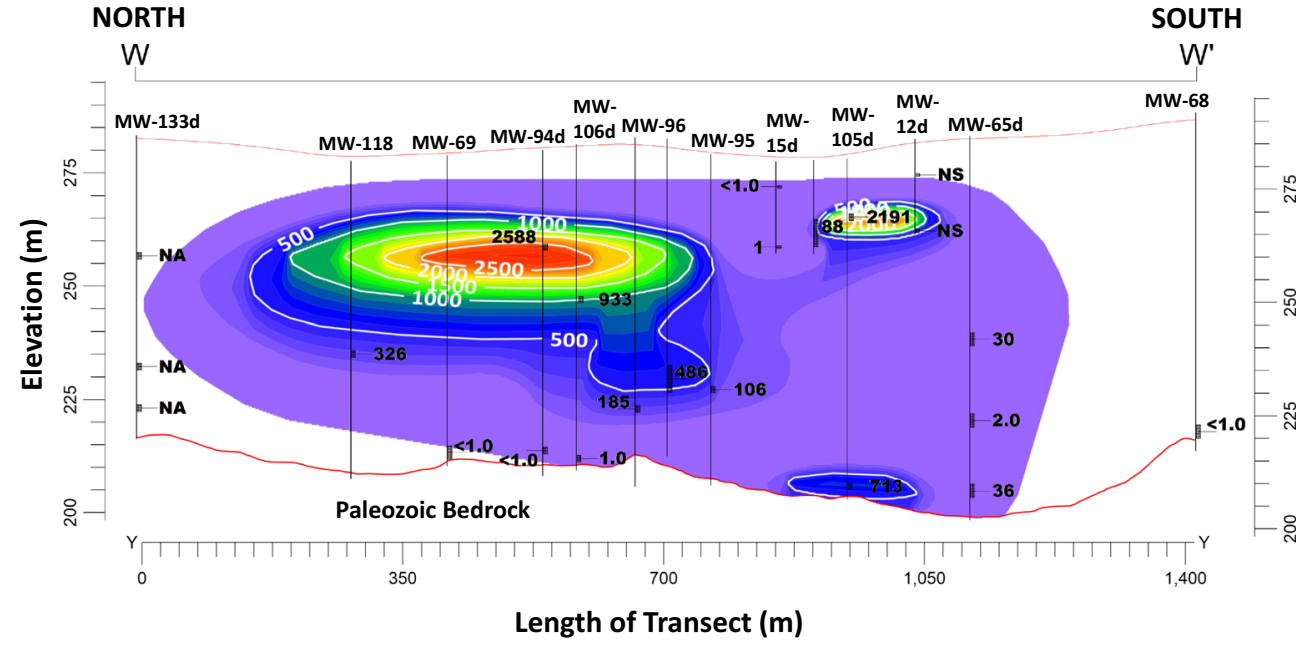

the MDEQ Gelman selected documents website (MDEQ 2018a). Annual estimates of 1,4-dioxane storage within the Eastern Area were generated using published concentration maps for 2005-2017 (FTCH 2005a, b, 2006, 2008a, b, 2009c; d; Pall Life Sciences 2006; Fleis and Vandenbrink 2010, 2011, 2012c, 2013, 2014, 2015, 2016c, 2017). Concentration contours at the detection limit of $1 \mathrm{ppb}$ were taken from maps generated by the Environmental Health Division of the Washtenaw County Health Department (Washtenaw County 2016). Shallow and deep plume concentration maps were digitized and integrated with net contaminated aquifer thickness maps over the Eastern Area at a 3 $\mathrm{m} \times 3 \mathrm{~m}(10 \mathrm{ft} \times 10 \mathrm{ft})$ resolution. A uniform porosity of $30 \%$ was assumed. Potential sinks such as sorption, biodegradation, uncharted flow paths bypassing the existing monitoring well network, and undocumented discharges to surface streams and storm drains were not included in the analysis. Estimated changes in 1,4-dioxane storage within the Eastern Area were then compared with mass flux estimates to determine potential surpluses or deficits in the mass balance.

\section{Spatial moments}

Plume-scale changes in the spatial and temporal distribution of 1,4-dioxane within the Eastern Area were further investigated using spatial moment analysis (Freyberg 1986). The Monitoring and Remediation Optimization System (MAROS 3.0) decision support software (Ling et al. 2004; GSI Environmental 2012) was utilized to determine changes in the zeroth, first, and second spatial moments from available monitoring well data. The zeroth spatial moment represents an integrated measure of the total dissolved contaminant mass. The first moment provides the geographic position of the center of mass, and its change in location over time can be used as an indicator of mean solute velocity. The second moment can be used to infer an expanding, stable, or shrinking plume. MAROS output also includes Mann-Kendall trend analysis to provide plume stability information (Ling et al. 2004).

Time series 1,4-dioxane concentration measurements from 52 monitoring wells were analyzed using MAROS over the period from 2006-2017. A uniform aquifer thickness of $40 \mathrm{~m}$ (130 ft) and a constant porosity of $30 \%$ were assumed. Yearly estimates of dissolved dioxane mass were plotted to evaluate trends in dioxane storage in the Eastern Area. Changes in the location of the center of mass were examined to evaluate plume stability.

\section{Results and discussion}

\section{Order-of-magnitude reduction}

Figure 5 compares the historic and most recent (2017) maximum concentrations for the 20 monitoring wells involved in the natural attenuation investigation. The well name designators 's' and ' $\mathrm{d}$ ' indicate shallow or deep screens at nested well locations but do not imply a particular absolute depth or elevation. Concentrations in most wells decreased between zero and one order-of-magnitude (Fig. 5; Table 2), similar to reductions reported by Adamson et al. (2015) for several 1,4-dioxane contaminated sites in California. The degree to which remediation and/or natural attenuation contributed to these concentration reductions is uncertain. Wells MW-72s and MW-15d experienced approximately two and four orders-ofmagnitude reductions respectively, and their observed concentrations dropped below the Michigan 1,4-dioxane standard of $7.2 \mathrm{ppb}$. Reductions in wells MW-15s and MW-15d can be attributed to their proximity, $30 \mathrm{~m}(90 \mathrm{ft})$, to a nearby extraction well. Concentration reductions in MW-72s, which is located $1,100 \mathrm{~m}(3,600 \mathrm{ft})$ downgradient from the nearest extraction well, are harder to explain, particularly when compared to MW-72d, which is screened $20 \mathrm{~m}(67 \mathrm{ft})$ lower in elevation. Significant differences in both the maximum dioxane concentrations and the degree of reduction observed in 
Fig. 5 Order of magnitude (OM) reductions of recent (2017) versus historical maximum well concentrations for 1,4-dioxane in the Eastern Area

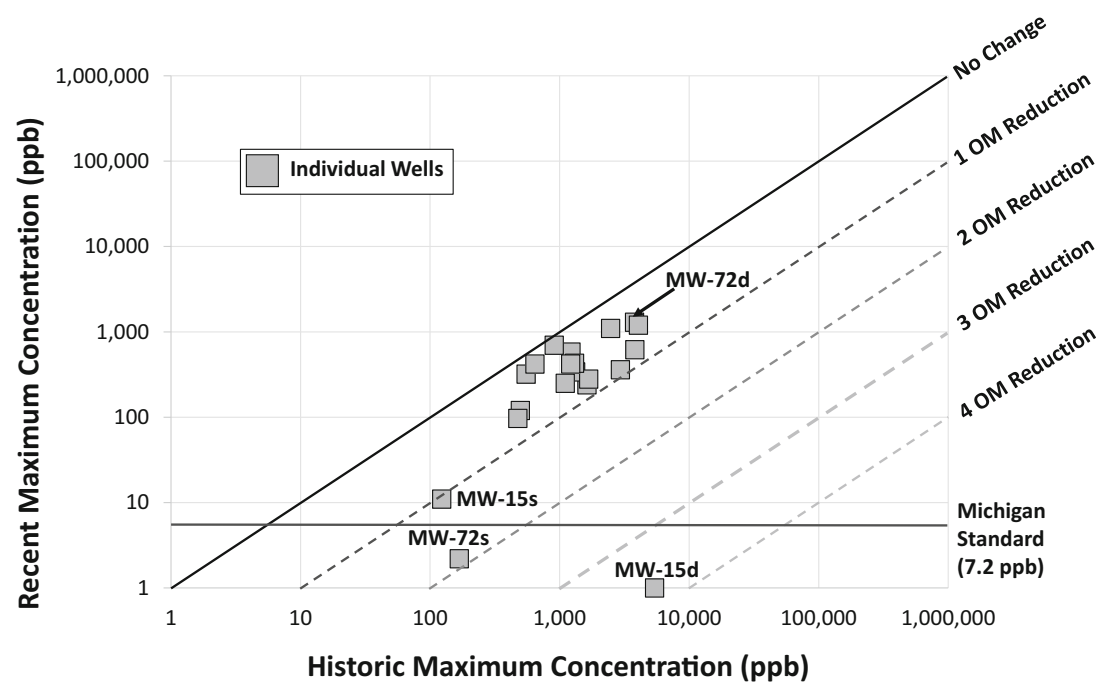

MW-72s and MW-72d illustrate differential migration of 1,4dioxane at various depths throughout the aquifer system that confound interpretation of order-of-magnitude analysis for individual wells.

\section{Point attenuation rates and half-lives}

Table 2 includes decay rate coefficients and half-lives calculated from first order regression analyses. Although concentrations are attenuated in every well, decay coefficients are small and predicted times for concentrations to fall below $7.2 \mathrm{ppb}$ exceed 50 years in many cases. Relatively slow decay rates such as these could result from steady contaminant loading and/or the absence of significant biodegradation. Variability in attenuation behavior among the wells analyzed may result from differential effects of remediation or spatial variability of conditions favoring biodegradation within the complex glacial aquifer system. Additional analyses involving multiple wells were therefore examined to evaluate natural attenuation at a larger scale.

\section{Bulk attenuation}

Reductions in concentrations over time at wells located along the inferred longitudinal axis of the plume indicate that attenuation is occurring at those wells. If biodegradation is responsible for all or part of this attenuation, contaminant transport theory suggests that maximum concentrations at well observation points should decrease with increasing migration from the source (Domenico and Schwartz 1998). In the Eastern Area plume axis wells, the natural log of the maximum historical concentration regressed as a function of transport distance from the source zone generated a small negative slope (Fig. 6, dashed line), which could be consistent with biodegradation but is not statistically significant $(p$-value $=0.34)$. A similar regression using the easternmost 6 points on the chart
(Fig 6., solid line), representing wells that are $500 \mathrm{~m}$ or more downgradient from purge wells TW-18 and TW-21 along Wagner Road, yields a statistically significant regression $(p-$ value $=0.037$ ).

The observed decrease in maximum concentrations among the easternmost six wells along the plume axis was used in conjunction with the assumed seepage velocity to estimate a bulk attenuation decay coefficient of 0.017 year $^{-1}$ (Eq. 4). The potential for 1,4-dioxane to reach the Huron River at the eastern boundary of the prohibition zone was then evaluated using estimated decay times (Eq. 5), and travel distances (Eq. 6), to decline to State of Michigan criteria. In MW-72d, dioxane concentrations began to decrease from maximum observed values of approximately 3,800 ppb beginning in 2012. Neglecting sorption and mass reductions from ongoing remediation, it would take an estimated 150 years along a potential transport distance of $17 \mathrm{~km}$ for dioxane concentrations to attenuate from 3,800 ppb to the groundwater/surface-water Interface (GSI) criterion of 280 $\mathrm{ppb}$. Alternatively, it would require approximately 370 years and $41 \mathrm{~km}$ to reach the $7.2 \mathrm{ppb}$ Michigan drinking water criterion. Further downgradient, near the mapped leading edge of the plume, well MW-83s recorded peak concentrations of approximately $650 \mathrm{ppb}$ in 2010. Similar calculations yielded attenuation time and distance estimates of 50 years $/ 5 \mathrm{~km}$ and 260 years $/ 29$ $\mathrm{km}$ to reach 280 or $7.2 \mathrm{ppb}$, respectively. Although the estimated travel times are sensitive to the assumed seepage velocity, the estimated travel distances are substantially larger than the $4.5 \mathrm{~km}$ length of the prohibition zone, suggesting high potential for 1,4dioxane to reach the Huron River at relevant regulatory concentrations.

These estimates do not include the benefits of active site remediation, however. As 1,4-dioxane continues to migrate through the Eastern Area, a combination of remediation and attenuation are expected to reduce concentrations, even if the source of the plume has not been completely contained or removed. Therefore, a mass balance evaluation on the 


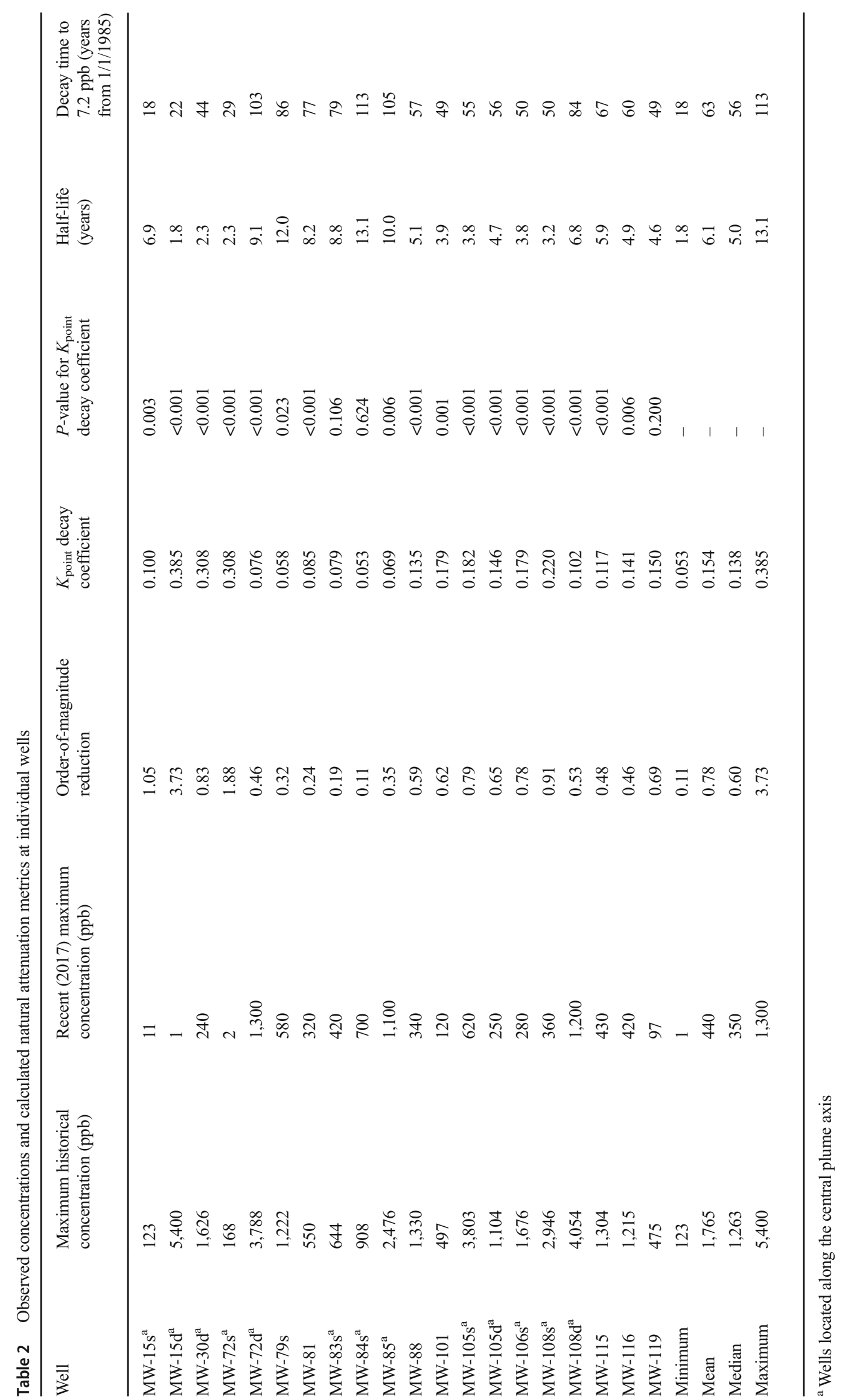


Fig. 6 Bulk attenuation of 1,4dioxane concentrations as a function of inferred transport distance along the central plume axis. Natural log of historical 1,4dioxane concentrations are shown by black squares and recent (2017) maximum concentrations are shown as gray circles. Regression lines for historical maximum concentrations: dashed $=$ all wells, solid $=$ easternmost six wells

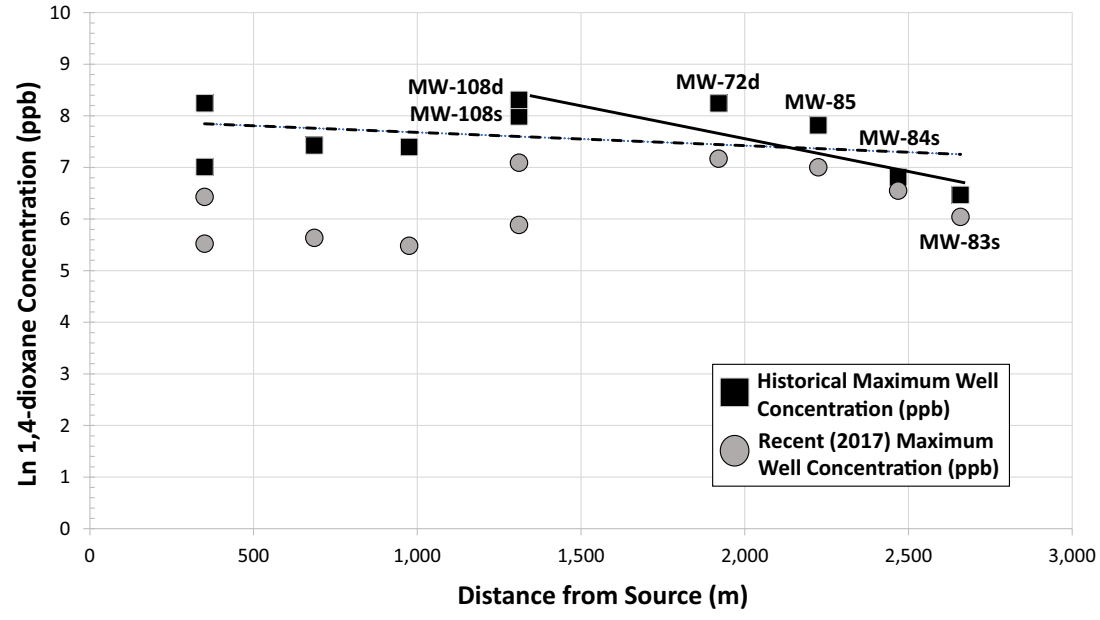

Eastern Area was completed using concentration data from 2005-2017 to evaluate the relative contributions of remedial and natural attenuation.

\section{Mass balance}

Figure 7 illustrates the areal distribution of 1,4-dioxane within the Eastern Area at the first (2005), middle, (2011) and final (2017) years of the analysis. A complete montage of maps illustrating changes in mapped 1,4-dioxane concentrations during the 12-year study period is provided in Fig. S5 of the ESM. Annual estimates of aqueous phase dioxane mass are plotted in Fig. 8. Total dioxane mass in the Eastern Area ranged from 13,000 to $17,000 \mathrm{~kg}$; however, the trend in mass storage shown in Fig. 8 indicates an increase followed by a reduction in mass during the period of investigation. From 2005 to 2011, 1,4-dioxane mass increased by approximately $3,600 \mathrm{~kg}$. In contrast, from 2011 to 2017, the mass of 1,4dioxane decreased by approximately $4,000 \mathrm{~kg}$ (Table 3 ). Mass balance calculations including estimated advective influx and measured remedial removal of dioxane, were therefore calculated separately for these two time periods.

1,4-Dioxane mass flux estimates across Wagner Road into the Eastern Area decreased from $150 \mathrm{~kg}$ /year in 2008 to $60 \mathrm{~kg}$ / year in 2012, and $40 \mathrm{~kg} /$ year in 2016. Decreasing dioxane transport into the Eastern Area over this time period is consistent with continuing pump-and-treat operations in extraction wells located on the former Gelman property and adjacent to Wagner Road. Assuming the mass influx rate was steady during the first 6 years, the 2008 influx estimate of $150 \mathrm{~kg} /$ year was extrapolated to generate an estimate of $900 \mathrm{~kg}$ influx from 2005 to 2011. Influx estimates for 2012 and 2016 were averaged and applied to generate an estimate of $300 \mathrm{~kg}$ during the period 2011-2017 (Table 3). During the same time periods, extraction wells within and adjacent to the Eastern Area removed 3,000 kg of dioxane from 2005-2011 and 2,100 kg of dioxane from 2011-2017 (Table 3).
Subsequent mass balance calculations yield a surplus of $5,700 \mathrm{~kg}$ during 2005-2011 and a deficit of 2,200 kg for 2011-2017 (Table 3). The net increase during the initial period represents an additional influx of approximately $950 \mathrm{~kg} / \mathrm{year}$ that is not accounted for by our estimates. Assuming that 1,4dioxane from this source continued to be added to the Eastern Area at the same rate during 2011-2017, the net mass deficit during 2011-2017 grows from 2,200 to 7,900 kg (1,300 kg/ year). With or without this inferred additional influx, mass balance results suggest that natural attenuation, potentially from biodegradation, played an important role in reducing observed concentrations at the Gelman Site during the latter half of the study period.

\section{Spatial moments}

MAROS site summary and moment analysis reports for the Eastern Area are presented in Figs. S6-S10 of the ESM. Results are generally consistent with the mass balance evaluation based on time series concentration maps (see section 'Mass balance evaluation'). Zeroth spatial moment calculations show a clear trend of increasing dioxane mass over the first 6 years of the study period followed by decreasing dioxane mass during the remainder (Fig. S8 of the ESM). MAROS estimated changes in storage during the first half $(+5,600 \mathrm{~kg})$ and second half $(-4,600 \mathrm{~kg})$ of the study period (Fig. S8 of the ESM) compare well with those estimated from the concentration maps (Table 3). Overall, the dioxane mass storage estimates from zeroth moments reported here are less than those calculated with mapped concentrations and aquifer thickness maps (Fig. 8). These estimates scale directly with the average aquifer thickness input parameter, however, and thus could be adjusted. Mass estimates from zeroth spatial moments interpolated using Delaunay triangles (Ling et al. 2004) are arguably more objective than their map-based counterparts. For this study, however, they are considered less robust because they depend on the spatial distribution of monitoring wells 
Fig. 7 1,4-Dioxane concentrations in the Eastern Area for years 2005, 2011, and 2017
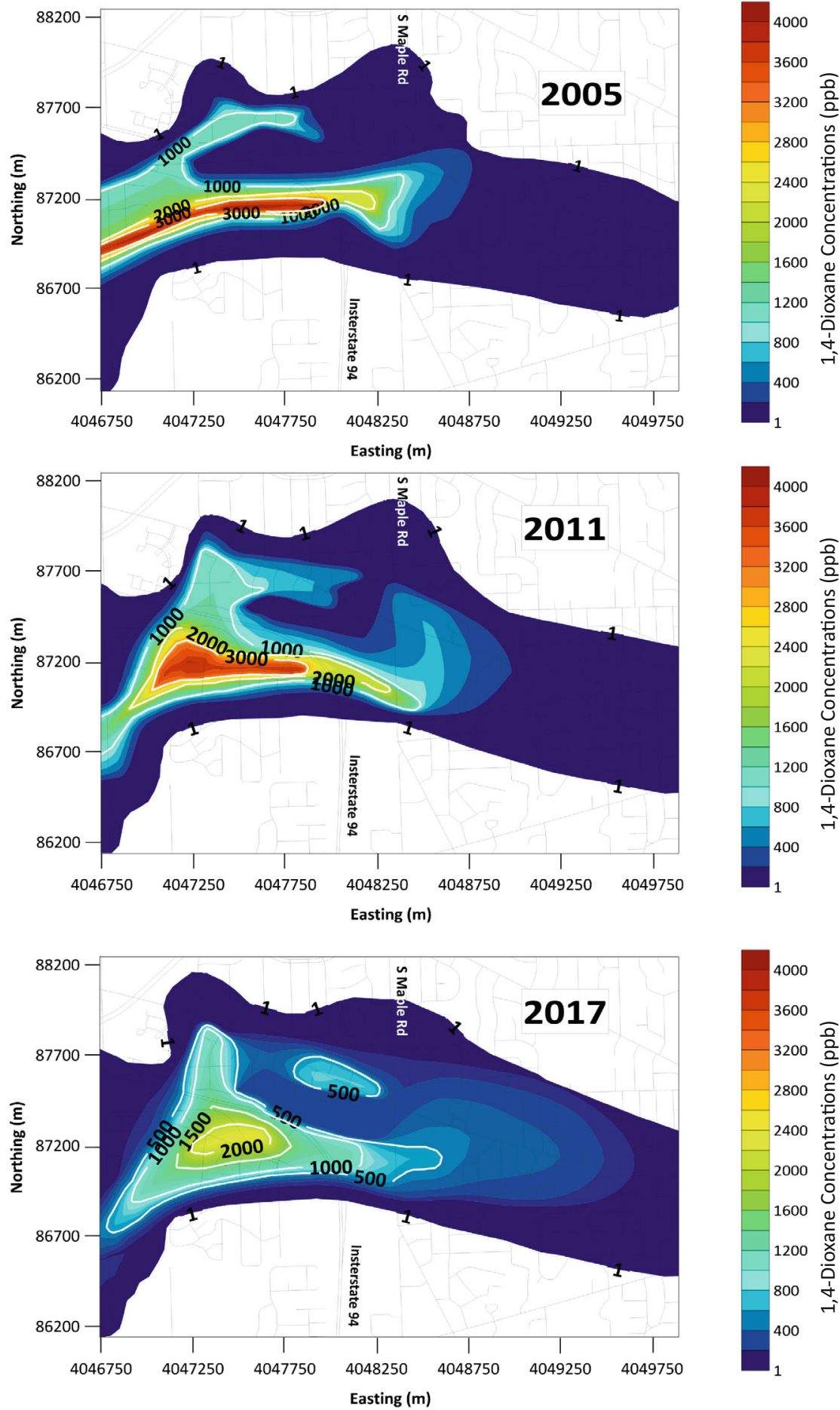

and may be subject to overshoot or undershoot resulting from steep gradients generated by closely spaced data points proximal to areas with no data (McLean et al. 2019).

First-order moment analysis indicates that the calculated distance from the source area to the center of mass increased by approximately $300 \mathrm{~m}(1,000 \mathrm{ft})$ during the study period (Fig. S9 of the ESM). The location of the center of mass was relatively stable during the first 7 years, however, followed by a period of moderate advance to the northeast from 2013 to 2017 (Figs. S9 and S10 of the ESM). This result may be driven by continuing migration of a dioxane slug beyond the reach of extraction wells in the vicinity of Wagner Road (i.e., near the western boundary of the Eastern Area) combined with the bifurcation of dioxane movement along two separate pathways to the east and northeast (Figs. 2 and Fig. 7 and Fig. S5 of the ESM). This result is interesting 
Fig. 8 Integrated 1,4-dioxane mass estimates in the Eastern Area for the years 2005-2017

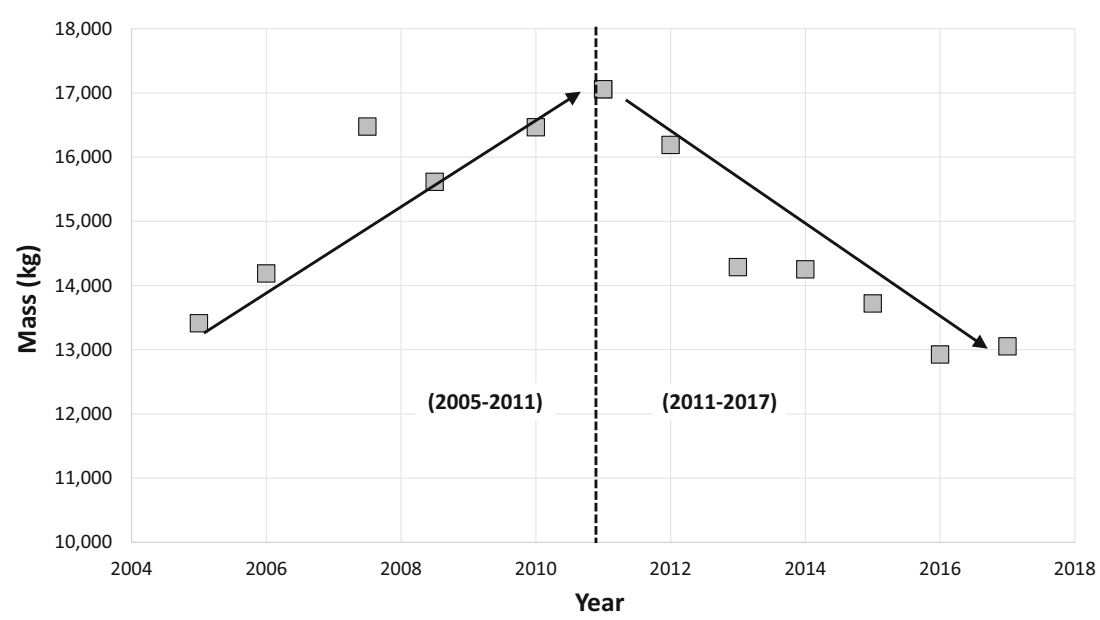

because it suggests that the center of mass may be advancing at the same time that the mapped leading edge appears to remain stable.

\section{Potential 1,4-dioxane attenuation processes}

Several potential mechanisms, including hydrodynamic dispersion, sorption, and biodegradation, may have contributed to the observed and inferred attenuation of dioxane in this study. In addition, mass flux through unidentified pathways offers another possible explanation for inferred 1,4-dioxane mass reductions in the Eastern Area. First order approximations using sorption coefficient $\left(K_{\mathrm{d}}\right)$ values inferred from the generally accepted range of retardation factors (ATSDR 2012) indicated that sorbed mass could equate to $5-30 \%$ of the total aqueous phase mass in the Eastern Area in 2011. However, declining aqueous phase 1,4-dioxane concentrations observed throughout the majority of the Eastern Area suggest that sorption processes did not represent a significant sink during the study period. Diffused mass estimates calculated using assumptions similar to those modeled by Adamson et al. (2016) also suggested that diffusion would not serve as a material source or sink of dioxane in the Eastern Area during the study period. Consequently, diffusion and sorption were assumed to be negligible in this investigation. Biodegradation and bypass are discussed in more detail in the following.
Aerobic biodegradation of 1,4-dioxane has been demonstrated in a growing number of laboratory investigations (e.g., Parales et al. 1994; Zenker et al. 2000; Kim et al. 2009; Sei et al. 2010; Mahendra et al. 2013; Li et al. 2014; Inoue et al. 2016; Zhou et al. 2016; Barajas-Rodriguez and Freedman 2018). Metabolic degradation of 1,4-dioxane has been demonstrated using a variety of bacterial strains including Pseudonocardia dioxanivorans CB1190 (Parales et al. 1994; Mahendra and Alvarez-Cohen 2005), P. benzenivorans B5 (Mahendra and Alvarez-Cohen 2006), and Mycobacterium sp. PH-06 (Kim et al. 2009). In the majority of these investigations, reduction of 1,4-dioxane concentrations was inversely related to increased bacterial cell growth, suggesting that these bacteria are capable of using 1,4-dioxane as a sole carbon and energy source. In cometabolic biodegradation studies, the addition of substrates such as tetrahydrofuran (THF) resulted in a lag time before 1,4-dioxane degradation was observed (Mahendra and Alvarez-Cohen 2006; Vainberg et al. 2006).

In recent field trials, Lippincott et al. (2015) stimulated in situ 1,4-dioxane biodegradation using propane bio-sparging and bioaugmentation at a United States Air Force base in California. Chu et al. (2018) demonstrated in situ aerobic cometabolic biodegradation of 1,4-dioxane to concentrations below $3 \mu \mathrm{g} / \mathrm{L}$ at the former McClellan Air Force Base near Sacramento, California.

Fewer investigations have examined 1,4-dioxane biodegradation under anaerobic conditions (Steffan 2007; Shen et al.

Table 3 Mass balance estimates

\begin{tabular}{llll}
\hline Parameter & Estimation method & 2005-2011 & 2011-2017 \\
\hline Changes in mass storage (kg) & $\begin{array}{c}\text { Interpolation from concentration } \\
\text { contour maps } \\
\text { Advective mass influx (kg) }\end{array}$ & 3,600 & $-4,000$ \\
Remediation mass removal (kg) & $\begin{array}{l}\text { Wagner Road } \\
\text { Integrated extraction well volumes } \\
\text { and concentrations }\end{array}$ & 3,000 & 300 \\
Net sources (kg) & $\begin{array}{l}\text { Back calculated } \\
\text { Back calculated }\end{array}$ & 5,700 & - \\
Net sinks $(\mathrm{kg})$ & $-2,100$ & $-2,200$ \\
\hline
\end{tabular}


2008; Sekar and DiChristina 2014; Arve 2015). Steffan (2007) was unable to stimulate 1,4-dioxane biodegradation under nitrate, iron, sulfate, and methanogenic reducing conditions. Shen et al. (2008) used enriched Fe(III)-reducing bacteria cultivated from municipal wastewater treatment sludge, in conjunction with humic acid, to stimulate the degradation of 1,4-dioxane under anaerobic conditions. The study noted that $50 \%$ of the 1,4-dioxane was mineralized. Sekar and DiChristina (2014) demonstrated 1,4-dioxane biodegradation in experiments conducted under alternating aerobic and anaerobic conditions. Increased biodegradation was observed during the aerobic cycles, and little to no degradation occurred during the anaerobic cycles. Experiments by Arve (2015) suggested the potential for anaerobic biodegradation of 1,4-dioxane in Fe(III)-humic acid amended microcosms with the addition of acetate. However, none of these investigations has convincingly demonstrated anaerobic biodegradation of 1,4-dioxane.

Unrecognized discharge into surface-water bodies represents another potential sink for 1,4-dioxane in the Eastern Area. Subsurface flow along preferential flow paths bypassing widely spaced monitoring wells in the easternmost Eastern Area could permit dioxane to travel undetected to the Huron River, the expected discharge location for the aquifer system (Pappas 2016; Pruehs 2016). Alternatively, 1,4-dioxane contaminated water could discharge into the Allen Creek drain system (Fig. 1), which includes five principle tributaries that converge into an engineered outlet at the Huron River. Artesian conditions in the eastern portion of the Eastern Area contribute to this possibility. Recent sampling within the Allen Creek-West Park SW storm drain detected 1,4-dioxane at concentrations in the range of 4-19 ppb (MDEQ 2017, 2018c). Although these observations fall below the Michigan GSI standard, the presence of dioxane suggests that contaminated groundwater may be discharging into the Allen Creek drain. Expansion of the downgradient monitoring well network and continued storm drain sampling are necessary to determine the extent of 1,4-dioxane discharge to the Allen Creek drain and Huron River.

\section{Limitations}

This study is limited by the temporal and spatial resolution, and, in some instances, the availability of the site data upon which it is based. The monitoring well network provides a set of discrete concentration measurements at positions that were chosen to optimize remedial objectives. Consequently, the spatial density of monitoring wells is greater closer to the source zone and becomes sparser toward the leading edges of the plume. As a result, uncertainty in the definition of mapped concentrations and inferred mass distributions increases from west to east across the study area.
Results of plume scale analyses such as the mass balance and spatial moment calculations employed here are dependent on the distribution of control points-for example, the first moment analysis indicates a shift in the center of mass of approximately $300 \mathrm{~m}(1,000 \mathrm{ft})$ to the northeast between 2006 and 2017 (Fig. S10 of the ESM). Possible effects of this shift on mass balance estimates have not been quantified in this study; however, the distance is small relative to the overall dimensions of the plume in the Eastern Area and the effects are therefore expected to be negligible.

In addition, wells at the Gelman Site are not all sampled at the same time. Some are sampled on a monthly basis, while others are sampled less frequently (annually, bi-annually, or quarterly). Thus, measurements used to identify annual or historical maxima, as well as the changing distribution of 1,4dioxane in the aquifer system, are subject to variable temporal resolution. Nevertheless, the 1,4-dioxane isoconcentration maps used to estimate changes in mass storage in this study were updated twice each year and are believed to provide a reasonable record of changes in 1,4-dioxane distributions over the 12-year study period.

Another limitation inherent in the 1,4-dioxane concentration map series is its utilization of the $85 \mathrm{ppb}$ contour to define the limits of groundwater contamination. This is a result of the applicable regulatory standard when the maps were made. A sensitivity analysis was run to determine the fraction of 1,4-dioxane mass stored in low concentration zones around the perimeter of the plume that is not included in our dioxane mass calculations. Using the $1 \mathrm{ppb}$ isoconcentration contour on the Washtenaw County Health Department Map (Washtenaw County, 2016), dioxane at concentrations between the 1 and 85 ppb contours was found to represent approximately $6 \%$ of the total mass, a relatively small fraction. Again, these calculations are based on maps that rely on the available monitoring well network and do not account for potential missing mass in areas where monitoring wells are absent.

First-order approximations suggested that sorption and diffusion cannot account for the inferred sources or sinks of dioxane in the Eastern Area during the study period; however, sitespecific sorption $\left(K_{\mathrm{d}}\right)$ values have not been quantified. A separate investigation to determine sorption capability of the aquifer and the aquitard materials is planned using sediments from a site core. Evidence for back diffusion of dioxane from low permeability zones is present in the form of asymptotic concentrations observed in extraction wells west of the study area. Quantification of diffusion dynamics and the magnitude of diffusive mass storage in the Eastern Area, where historically lower concentrations have been observed, would require a separate modeling effort that is beyond the scope of this study.

Finally, although this study provides indirect evidence for biodegradation at the Gelman Site, quantification of degradation rates is not possible from the methods employed. Direct evidence, in the form of microcosm experiments using 
environmental samples from the site, is required to confirm biodegradation activity. Relevant geochemical data characterizing subsurface REDOX conditions are not available in the public domain; however, geochemical measurements collected during low flow testing of six Eastern Area wells from December 2016 through March 2019 was recently released (D. Hamel, Michigan Department of Environment, Great Lakes, and Energy, unpublished data, 2019). The wells are screened at depths ranging from 29 to $53 \mathrm{~m}(94-174 \mathrm{ft})$ and are positioned along the central axis as well as the mapped perimeter of the plume (as defined by $85 \mathrm{ppb}$ contour). These measurements demonstrate a wide variability in dissolved oxygen (DO) concentrations ranging from -0.05 to $3.28 \mathrm{mg} / \mathrm{L}$, representing saturations of 0-22\% oxygen based on equilibrium with the atmosphere at the respective sample temperatures. Oxidationreduction potential (ORP) values ranged from -317 to +138 $\mathrm{mV}$, suggesting anaerobic conditions in the range generally associated with nitrate and manganese reduction. These data displayed both temporal and spatial variability that is not readily explained by their position with respect to the plume. They may therefore reflect complexity that is governed by subsurface physical and biological heterogeneity. Determining the likelihood of aerobic and/or anaerobic biodegradation will require carefully designed microcosm experiments using 1,4-dioxane contaminated groundwater from the Gelman Site.

\section{Conclusions}

This investigation examined evidence for natural attenuation within a multi-layered aquifer system beneath the city of Ann Arbor, Michigan, USA. Results of the study are mixed. Observed decreases in 1,4-dioxane concentrations in monitoring wells within the Eastern Area of the Gelman Site demonstrate that attenuation is occurring. Most wells with decreasing concentrations have experienced less than one order of magnitude reduction, although several wells exhibited greater reductions that can be attributed to ongoing remediation. Small decay coefficients and large time estimates for concentration reductions to the Michigan drinking water criterion at individual wells indicate that natural attenuation may be occurring at rates that are too slow to meaningfully affect remediation results without enhancements (e.g., Lippincott et al. 2015). In contrast, mass balance and spatial moment analyses suggest that natural attenuation is occurring at a rate that could potentially contribute to remediation efforts. The estimated decrease in 1,4-dioxane mass storage during the second half of the study is approximately twice that of the mass extracted during the same period (Table 3). This implies that natural attenuation was responsible for removal of 1,4-dioxane from the Eastern Area at a rate similar to remedial pump-and-treat during 20112017.
1,4-Dioxane has been thought to resist attenuation due to its high miscibility, lack of sorption potential, and recalcitrant chemical structure. Nevertheless, the findings of this study and others (Mahendra and Alvarez-Cohen 2006; Mahendra et al. 2013; Li et al. 2010, 2015; Adamson et al. 2015; Gedalanga et al. 2016) provide evidence to suggest that 1,4-dioxane is subject to natural attenuation processes, including biodegradation. Evidence from the Eastern Area of the Gelman Site is insufficient to determine to what extent observed attenuation results from biodegradation, uncharted flows along preferential pathways, or surface discharges through storm drain systems, however. Thus, additional site-specific studies evaluating natural attenuation mechanisms including biodegradation along with hydrogeologic and numerical modeling studies to evaluate flow paths and surface discharge are necessary to support the findings in this study. The uncertainties illustrated here, coupled with the expensive and time-consuming nature of advanced oxidation treatments, underscore the need to better understand the ability of natural attenuation to enhance cleanup efficiency and potentially reduce costs at 1,4-dioxane contaminated sites.

Acknowledgements The authors thank the Michigan Department of Environmental Quality, the City of Ann Arbor, the Washtenaw County GIS Program, Scio Residents for Safe Water, and Pall Life Sciences for assistance with data access. Conversations with Dan Hamel, Kevin Lund, Jim Brode, Farsad Fotouhi, Roger Rayle, and Matt Naud contributed to the authors' understanding of this site. Caitlin Bristol and Kammie Hauger assisted in extensive data assembly and analysis. Thoughtful criticism from the associate editor and two anonymous reviewers improved the content and clarity of this paper.

Funding information Financial support for this research was provided by the Earth and Ecosystem Science doctoral program at Central Michigan University.

Open Access This article is distributed under the terms of the Creative Commons Attribution 4.0 International License (http:// creativecommons.org/licenses/by/4.0/), which permits unrestricted use, distribution, and reproduction in any medium, provided you give appropriate credit to the original author(s) and the source, provide a link to the Creative Commons license, and indicate if changes were made.

\section{References}

Adamson DT, Anderson HR, Mahendra S, Newell CJ (2015) Evidence of 1,4-dioxane attenuation at groundwater sites contaminated with chlorinated solvents and 1,4-dioxane. Environ Sci Tech 49(11): 6510-6518. https://doi.org/10.1021/acs.est.5b00964

Adamson DT, de Blanc PC, Farhat SK, Newell CJ (2016) Implications of matrix diffusion on 1,4-dioxane persistence at contaminated groundwater sites. Sci Total Environ 562:98-107. https://doi.org/10.1016/j. scitotenv.2016.03.211

Alvarez PJJ, Illman WA (2006) Bioremediation and natural attenuation: process fundamentals and mathematical models. Wiley, Chichester, UK

Arve P (2015) Microcosm study of 1,4-dioxane biotransformation. MSc Thesis, Clemson University, South Carolina, USA. https:// 
tigerprints.clemson.edu/cgi $/$ viewcontent.cgi? article= 3198\&context=all theses. Accessed 23 October 2018

ATSDR (2012) Toxicological Profile for 1,4-dioxane. Agency for Toxic Substances \& Disease Registry. https:/www.atsdr.cdc.gov/ toxprofiles/TP.asp?id=955\&tid=199. Accessed 23 October 2018

Barajas-Rodriguez FJ, Freedman DL (2018) Aerobic biodegradation kinetics for 1,4-dioxane under metabolic and cometabolic conditions. J Hazard Mater 350:180-188. https://doi.org/10.1016/j.jhazmat. 2018.02.030

Chu M-YJ, Bennett PJ, Dolan ME, Hyman MR, Peacock AD, Bodour A, Anderson RH, Mackey DM, Goltz MN (2018) Concurrent treatment of 1,4-dioxane and chlorinated aliphatics in a groundwater recirculation system via aerobic cometabolis. Groundw Monitor Remed 38(3):53-64. https://doi.org/10.1111/gwmr.12293

City of Ann Arbor (2004) A brief history of the Ann Arbor groundwater contamination problem. https://www.a2gov.org/departments/ systems-planning/planning-areas/climate-sustainability/pls/Pages/ timeline.aspx. Accessed 07 November 2018

Cypher JA, Lemke LD (2009) Multiple working transport hypotheses in a heterogeneous glacial aquifer system. Groundw Monitor Remed 29(3):105-119. https://doi.org/10.1111/j.1745-6592.2009.01245.x.

DiGuiseppi W, Walecka-Hutchison C, Hatton J (2016) 1,4-Dioxane treatment technologies. Remediation 27(1):71-92. https://doi.org/10. 1002/rem.21498

Domenico PA, Schwartz FW (1998) Modeling the transport of dissolved contaminants. In: Mills C (ed) Physical and chemical hydrogeology, 2nd edn. Wiley, New York, pp 376-377

Fleis and Vandenbrink (2010) 1,4-Dioxane isoconcentration map for Unit E (May-Aug. 2010). https://www.michigan.gov/documents/deq/ deq-rrd-GS-3rdQuarter2010DeepPlumeMapSept2010_337260_7. pdf. Accessed 23 October 2018

Fleis and Vandenbrink (2011) 1,4-Dioxane isoconcentration map for Unit E (Sept. 2010-Mar. 2011). https://www.michigan.gov/documents/ deq/deq-rrd-GS-QuarterlyReport-DeepPlume 351283 7.pdf. Accessed 23 October 2018

Fleis and Vandenbrink (2012a) Potentiometric surface map: units $\mathrm{D}_{2}$ and E (September 19, 2012). https://www.michigan.gov/documents/ deq/deq-rrd-GS-CombinedWaterLevels3rdqutr_403555_7.pdf. Accessed 23 October 2018

Fleis and Vandenbrink (2012b) Potentiometric surface map: Unit E (September 19, 2012). https://www.michigan.gov/documents/deq/ deq-rrd-GS-3rdQrtrDeepWaterLevels_403557_7.pdf. Accessed 23 October 2018

Fleis and Vandenbrink (2012c) 1,4-Dioxane isoconcentration map for Unit E (April 2012-August 2012). https://www.michigan.gov/ documents/deq/deq-rrd-GS-DeepPlume3rdqutr_403553_7.pdf. Accessed 23 October 2018

Fleis and Vandenbrink (2013) 1,4-Dioxane isoconcentration map: Unit E (April 2013-September 2013). https://www.michigan.gov/ documents/deq/deq-rrd-GS-QuarterlyReport-3rdQuarter-2013DeepPlumes_437896_7.pdf. Accessed 23 October 2018

Fleis and Vandenbrink (2014) 1,4-Dioxane isoconcentration map: Unit E (May 2014-September 2014). https://www.michigan.gov/ documents/deq/deq-rrd-GS-3rdQuarterlyReports-DeepPlume_ 472295 7.pdf. Accessed 23 October 2018

Fleis and Vandenbrink (2015) 1,4-Dioxane isoconcentration map: Unit E (April 2015-October 2015). https://www.michigan.gov/documents/ deq/deq-rrd-GS-DeepPlume3rdQuarterProgressReport2015 504441 7.pdf. Accessed 23 October 2018

Fleis and Vandenbrink (2016a) Potentiometric surface map: units $\mathrm{D}_{2}$ and E (September 21, 2016). https://www.michigan.gov/documents/ deq/deq-rrd-GS-3rdQuarterReportCombinedWaterLevels_538704_ 7.pdf. Accessed 23 October 2018

Fleis and Vandenbrink (2016b) Potentiometric surface map unit E (September 21, 2016). https://www.michigan.gov/documents/deq/
deq-rrd-GS-3rdQuarterlyReportDeepWaterLevels_538701_7.pdf. Accessed 23 October 2018

Fleis and Vandenbrink (2016c) 1,4-Dioxane isoconcentration map: Unit E (May 2016-September 2016). https://www.michigan.gov/ documents/deq/deq-rrd-GS-3rdQuarterReportDeepPlume 538700 7.pdf. Accessed 23 October 2018

Fleis and Vandenbrink (2017) 1,4-Dioxane isoconcentration map unit E (October 2016-April 2017). https://www.michigan.gov/documents/ deq/deq-rrd-GS-1stQuarter2017Report-DeepPlume_571536_7.pdf. Accessed 23 October 2018

Fotouhi F, Tousi S, Brode Jr JW (2006) Managing a significant release of 1,4-dioxane into a complex glacial depositional environment: the integration of hydrogeology, remedial engineering and politics. Groundwater Resources Association of California, oral presentation, Concord CA, June 7-8, 2006

Frahm A (2011) Deterministic hydrogeologic modeling of glacial sediments, Washtenaw County, Michigan. MSc Thesis, Wayne State University, Michigan, USA. https://digitalcommons.wayne.edu/ oa theses/142/. Accessed 23 October 2018

Freyberg DL (1986) A natural gradient experiment on solute transport in a sand aquifer: 2. spatial moments and the advection and dispersion of nonreactive tracers. Water Resour Res 22(13):2031-2046. https:// doi.org/10.1029/WR022i013p02031

FTCH (2005a) Unit E aquifer 1,4-dioxane isoconcentration map: AprilMay 2005. Fishbeck, Thompson, Carr and Huber https://drive. google.com/drive/folders/0BzSYF0FH8viaeEZ4X212YXh4M1k. Accessed 23 October 2018

FTCH (2005b) Units C3, D2, D0 and SW property 1,4-dioxane isoconcentration contour map: April-May 2005. Fishbeck, Thompson, Carr and Huber. https:/drive.google.com/drive/folders/ 0BzSYF0FH8viaeEZ4X212YXh4M1k. Accessed 23 October 2018

FTCH (2006) Units $\mathrm{C}_{3}, \mathrm{D}_{2}, \mathrm{D} 0$ and SW property 1,4-dioxane isoconcentration contour map: April-September 2006. Fishbeck, Thompson, Carr and Huber. https://drive.google.com/drive/folders/ 0BzSYF0FH8viaU3BJNjJqbilISUU. Accessed 23 October 2018

FTCH (2008a) Unit E 1,4-dioxane isoconcentration map October 2007 March 2008. Fishbeck, Thompson, Carr and Huber. https://drive. google.com/drive/folders/0BzSYF0FH8viaMi1UWUpnQUZrTGs. Accessed 23 October 2018

FTCH (2008b) Units C3, D2, D0 and SW property 1,4-dioxane isoconcentration contour map: October 2007-March 2008, Fishbeck, Thompson, Carr and Huber. https://drive.google.com/drive/folders/ 0BzSYF0FH8viaMi1UWUpnQUZrTGs. Accessed 23 October 2018

FTCH (2009a) D2 and portions of unit E aquifer potentiometric surface contour map: March 17, 2009. Fishbeck, Thompson, Carr and Huber. https://www.michigan.gov/documents/deq/deq-rrd-GS-D2E-PSC-Map 285417 7.pdf. Accessed 23 October 2018

FTCH (2009b) Unit E potentiometric surface contour map: March 17, 2009. Fishbeck, Thompson, Carr and Huber. https://www.michigan. gov/documents/deq/deq-rrd-GS-E-PSCMarch-17-2009-Map 285419_7.pdf. Accessed 23 October 2018

FTCH (2009c) Unit E 1,4-dioxane isoconcentration map: October 2008March 2009. Fishbeck, Thompson, Carr and Huber. https://drive. google.com/drive/folders/0BzSYF0FH8viaNXBYOWRGR19UVXc. Accessed 23 October 2018

FTCH (2009d) Units C3, D2, D0 and SW Property 1,4-dioxane isoconcentration map: October 2008-March 2009. Fishbeck, Thompson, Carr and Huber. https://drive.google.com/drive/folders/ 0BzSYF0FH8viaNXBYOWRGR19UVXc. Accessed 23 October 2018. Accessed 23 October 2018

Gedalanga P, Madison A, Miao YR, Richards T, Hatton J, DiGuiseppi WH, Wilson J, Mahendra S (2016) A multiple lines of evidence framework to evaluate intrinsic biodegradation of 1,4-dioxane. Remediation 27(1):93-114. https://doi.org/10.1002/rem.21499

GSI Environmental (2012) Monitoring and Remediation Optimization System (MAROS) Software version 3.0 user's guide and technical 
manual. GSI Job no. 3489, Air Force Center for Engineering and the Environment, Port San Antonio, TX

Inoue D, Tsunoda T, Sawada K, Yamamoto N, Saito Y, Sei K, Ike M (2016) 1,4-Dioxane degradation potential of members of the genera Pseudonocardia and Rhodococcus. Biodegradation 27:277-286. https://doi.org/10.1007/s10532-016-9772-7

Kim Y-M, Jeon J-R, Murugesan K, Kim E-J, Chang Y-S (2009) Biodegradation of 1,4-dioxane and transformation of related cyclic compounds by a newly isolated Mycobacterium sp. PH-06. Biodegradation 20:511-519. https://doi.org/10.1007/s10532-008-9240-0

Lemke LD, Frahm AL, Pappas LK (2013) Hybrid deterministic and stochastic hydrostratigraphic modeling of a complex glacial aquifer system; Three-Dimensional Geologic Mapping Workshop, Geological Society of America National Meeting, October 26, 2013, Minnesota Geological Survey Open File Report, OFR-13-2, pp 53-57, MGS, St Paul, MN

Li M, Fiorenza S, Chatham JR, Mahendra S, Alvarez PJJ (2010) 1,4Dioxane biodegradation at low temperatures in Arctic groundwater samples. Water Res 44(9):2894-2900. https://doi.org/10.1016/j. watres.2010.02.007

Li M, Mathieu J, Liu Y, Tess Van Orden E, Yang Y, Fiorenza S, Alvarez PJJ (2014) The abundance of tetrahydrofuran/dioxane monooxygenase genes $($ thmA/dxmA) and 1,4-dioxane degradation activity are significantly correlated at various impacted aquifers. Environ Sci Tech Lett 1: 122-127. https://doi.org/10.1021/ez400176h

Li M, Tess Van Orden E, DeVries DJ, Xiong Z, Hinchee R, Alvarez PJ (2015) Bench-Scale biodegradation tests to assess natural attenuation potential of 1,4-dioxane at three sites in California. Biodegradation 26(1):39-50. https://doi.org/10.1007/s10532-0149714-1

Ling M, Rifai HS, Aziz JJ, Newell CJ, Gonzales JR, Santillan JM (2004) Strategies and decision-support tools for optimizing long-term groundwater monitoring plans: MAROS 2.0. Bioremed J 8(3-4): 109-128. https://doi.org/10.1080/10889860490887491

Lippincott D, Streger SH, Schaefer CE, Hinkle J, Stormo J, Steffan RJ (2015) Bioaugmentation and propane biosparging for in situ biodegradation of 1,4-dioxane. Groundw Monitor Remed 35(2):81-92. https://doi.org/10.1111/gwmr.12093

Mahendra S, Alvarez-Cohen L (2005) Pseudonodcardia dioxanivorans sp nov.: a novel actinomycete that grows on 1,4-dioxane. Int $\mathrm{J}$ System Evolution Microbiol 55:593-598. https://doi.org/10.9999/ ijs. $0.63085-0$

Mahendra S, Alvarez-Cohen L (2006) Kinetics of 1,4-dioxane biodegradation by monooxygenase-expressing bacteria. Environ Sci Tech 40(17):5435-5442. https://doi.org/10.1021/es060714v

Mahendra S, Grostern A, Alvarez-Cohen L (2013) The impact of chlorinated solvent co-contaminants on the biodegradation kinetics of $1,4-$ dioxane. Chemosphere 91(1):88-92. https://doi.org/10.1016/j. chemosphere.2012.10.104

McLean MI, Evers L, Bowman AW, Bonte M, Jones WR (2019) Statistical modelling of groundwater contamination monitoring data: a comparison of spatial and spatiotemporal methods. Sci Total Environ 652:1339-1346. https://doi.org/10.1016/j.scitotenv.2018. 10.231

MDEQ (2017) Gelman Sciences recent analytical data, DEQ SEEP and surface water sample results, Dec 2017, 2nd Group. Michigan Department of Environmental Quality. https://www.michigan.gov/ documents/deq/deq-rrd-GS-DEQ-SEEP-SurfaceWaterResults 612426 7.pdf. Accessed 23 October 2018

MDEQ (2018a) Gelman Sciences selected documents. Michigan Department of Environmental Quality. https:/www.michigan.gov/ deq/0,4561,7-135-3311 $41099846 \quad 30022-72394 \% 2 \mathrm{D} \% 2 \mathrm{D}, 00$. html. Accessed 23 October $20 \overline{18}$

MDEQ (2018b) Gelman Sciences, Inc. site of contamination information page. Michigan Department of Environmental Quality. https://www.
michigan.gov/deq/0,4561,7-135-3311_4109_9846-71595\%2D\% 2D,00.html. Accessed 23 October 2018

MDEQ (2018c) Gelman Sciences recent analytical data, DEQ SEEP and surface water sample results, Dec 2017, 2nd Group. Michigan Department of Environmental Quality. https://www.michigan.gov/documents/deq/deqrrd-GS-SEEPSurfaceWaterSamplingSeptember2018_637311_7.pdf. Accessed 13 November 2018

Mohr TKG (2010) Environmental investigation and remediation: 1,4dioxane and other solvent stabilizers. CRC, Boca Raton, FL

Pall Life Sciences (2006) Phase 1 downgradient investigation Unit E plume. https://www.michigan.gov/documents/deq/deq-rrd-GSDowngradientGWInvestigationPhaseIForUnitE_290575_7.pdf. Accessed 23 October 2018

Pall Life Sciences (2007a) Phase 2 report: downgradient groundwater investigation of the Unit E Plume. https://www.michigan.gov/ documents/deq/deq-rrd-GS-DowngradientGWInvestigationPhase 216276_7.pdf. Accessed 23 October 2018

Pall Life Sciences (2007b) Evergreen System Review. https://www.michigan. gov/documents/deq/rrd-GS-EntireEvergreenReviewReport_197763_7. pdf. Accessed 23 October 2018

Pall Life Sciences (2009) 3rd quarter, 2009 (July, August, September). https://www.michigan.gov/documents/deq/deq-rrd-GSPLSQuarterlyReport3rdqtr12009_298648_7.pdf. Accessed 23 October 2018

Pappas LK (2016) Integration of deterministic and stochastic models of 1, 4-dioxane contaminated glacial aquifer system, Washtenaw County, Michigan. MSc Thesis, Wayne State University, Michigan, USA. https://digitalcommons.wayne.edu/oa theses/500/. Accessed 23 October 2018

Parales RE, Adamus JE, White N, May HD (1994) Degradation of 1,4dioxane by actinomycete in pure culture. Appl Environ Microbiol 60(12):4527-4530

Pruehs A (2016) Modeling bedrock transmissivity: implications for contaminant transport in an overlying glacial aquifer system. MSc Thesis, Wayne State University, Michigan, USA. https:// digitalcommons.wayne.edu/oa theses/503/. Accessed 23 October 2018

Shen W, Chen H, Pan, S (2008) Anaerobic biodegradation of 1,4-dioxane by sludge enriched with iron-reducing microorganisms. Bioresource Technology 99:2483-2487. https://doi.org/10.1016/j.biortech.2007. 04.054

Sei K, Kakinoki T, Inoue D, Soda S, Fujita M, Ike M (2010) Evaluation of the biodegradation potential of 1,4-dioxane in river, soil and activated sludge samples. Biodegradation 21:585-591. https://doi.org/10. 1007/s10532-010-9326-3

Sekar R, DiChristina TJ (2014) Microbially driven Fenton reaction for degradation of the widespread environmental contaminant 1,4-dioxane. Environ Sci Tech 48(21):12858-12867. https://doi.org/10. $1021 / \mathrm{es} 503454 \mathrm{a}$

Stefan MI, Bolton JR (1998) Mechanism of the degradation of 1,4-dioxane in dilute aqueous solutions using UV/hydrogen peroxide processes. Environ Sci Tech 32(11):1588-1595. https://doi.org/10. 1021/es970633m

Steffan RJ (2007) Biodegradation of 1,4-dioxane, SERDP Project ER1422 final report. https://www.serdp-estcp.org/Program-Areas/ Environmental-Restoration/Contaminated-Groundwater/EmergingIssues/ER-1422. Accessed 23 October 2018

Stepien DK, Diehl P, Helm J, Thomas A, Püttmann W (2014) Fate of 1,4dioxane in the aquatic environment: from sewage to drinking water. Water Res 48:406-419. https://doi.org/10.1016/j.watres.2013.09. 057

USEPA (2002) Calculation and use of first-order rate constants for monitored natural attenuation. EPA/540/S-02/500, US Environmental Protection Agency. https://nepis.epa.gov/Exe/ZyPDF.cgi/ 10004674.PDF?Dockey=10004674.PDF. Accessed 23 October 2018 
USEPA (2006) Treatment technologies for 1,4-dioxane: fundamentals and field applications. EPA-542-R-06-009, US Environmental Protection Agency. https://nepis.epa.gov/Exe/ZyPDF.cgi/ P1000YNN.PDF?Dockey=P1000YNN.PDF. Accessed 23 October 2018

USEPA (2017) Technical fact sheet-1,4-dioxane. EPA 505-F-17-011, US Environmental Protection Agency. https://www.epa.gov/sites/ production/files/2014-03/documents/ffrro_factsheet_contaminant 14-dioxane january2014_final.pdf. Accessed 23 October 2018

Vainberg S, Mcclay K, Masuda H, Root D, Condee C, Zylstra GJ, Steffan RJ (2006) Biodegradation of ether pollutants by Pseudonocardia sp. strain ENV478. Appl Environ Microbiol 72:5218-5224. https://doi. org/10.1128/AEM.00160-06

Washtenaw County (2016) Pall Life Sciences 1,4-dioxane plumes and assorted well locations. Washtenaw County Environmental
Services Division, Department of Planning and Environment. https://www.washtenaw.org/DocumentCenter/View/5114/14Dioxane-Plume-Map-PDF. Accessed 23 October 2018

Zenker MJ, Borden RC, Barlaz MA (2000) Mineralization of 1,4-dioxane in the presence of a structural analog. Biodegradation 11:239-246. https://doi.org/10.1023/A:1011156924700

Zenker MJ, Borden RC, Barlaz MA (2003) Occurrence and treatment of 1,4-dioxane in aqueous environments. Environ Eng Sci 20(5):423432. https://doi.org/10.1089/109287503768335913

Zhou YY, Huang H, Shen D (2016) Multi-substrate biodegradation interaction of 1,4-dioxane and BTEX mixtures by Acinetobacter baumannii DD1. Biodegradation 27:37-46. https://doi.org/10. 1007/s10532-015-9753-2 